\title{
DEVELOPMENT AND EVALUATION OF OFF-FIELD HYDRAULIC MOBILE RICE STRAW BALER
}

\author{
R. A. Hegazy $^{1}$
}

\section{ABSTRACT}

Majority of rice straw still unused, together with the unfavorable effects of field burning, environmental pollution and GHG emissions caused by it. Same time, straw baling has not been improved much to fit small-scale farming systems. Therefore, a small-scale mobile baler for baling straw piles created by stationary threshers or collected after combine harvesters has been developed to provide suitable bales' weight and dimensions to fit small-scale farmers' need and easy to be handled. The hydraulic based baler was manufactured in local workshop to be operated by 5-10 hp engine or 3 to $10 \mathrm{hp}$ electrical motor. Manufactured baler has been tested and evaluated in International Rice Research Institute, Los Baños, Philippines during year 2013-2014. Major components of baler were; hydraulic system consisted of vane pump, topported pressure filter, pressure gauge, sight gauge, return filter and piston with $600 \mathrm{~mm}, 0.083 \mathrm{~m} / \mathrm{s}$ and $0.069 \mathrm{~m} / \mathrm{s}$ stroke length, forward speed and return speed respectively; baler body with compression chamber has dimensions of $600 \times 350 \times 450 \mathrm{~mm}$ (height $x$ width $\times$ length); and transmission systems. Testing and evaluation of the baler gave chance to enhance baling mechanism and its reliability. The relations between straw characteristics, moisture content (MC) and bales density have been addressed, where $244.63 \mathrm{~kg} \mathrm{~m}^{-3}$ average bales density obtained from threshed straw with $49.84 \%$ average MC with $23.63 \mathrm{~kg}$ average weight. For lower MC, 6.31, 7.77 and 8.21\% bales density were 130.37, 145.63 and $137.53 \mathrm{~kg} \mathrm{~m}^{-3}$ respectively for different rice straw. Baling straw with same characteristics at different $M C$ reduced bales density by $21.3 \%$ when MC reduced from 25.23 to $7.77 \%$. Baling shorter straw gave higher bales density with $293.22 \mathrm{~kg} \mathrm{~m}^{-3}$ with $28.33 \mathrm{~kg}$ average bales' weight. Rice straw baled under low moisture content when gets stored indoors for 22 days, always had an increase in its moisture content as

\footnotetext{
${ }^{1}$ Assistant Professor, Agric. Eng. Dept., Faculty of Agric., Kafrelsheikh University
} 
well as the density. Also, for the verities that stored indoors long time (62 days), moisture content increased.

Keywords: Rice straw, straw characteristics, stationery baler, densification, hydraulic baling

\section{INTRODUCTION}

long with the progress in the rice production system, the amount
of straw will increase. About 620 million tons of rice straw
produced in 2008 in Asia and now approximately 731 million tons per year rice straw is produced globally (Africa: 20.9 million tons, Asia: 667.6 million tons, Europe: 3.9 million tons, America: 37.2 million tons, and Oceania: 1.7 million tons) (Gummert, 2013; Sarkar and Aikat, 2013). Only about $20 \%$ of rice straw was used for purposes such as producing ethanol, paper, fertilizers and fodders and the remaining amount is either removed from the field, in situ burned, piled or spread in the field, incorporated in the soil, or used as mulch for the following crop (Hanafi et al., 2012). In many developing countries, straw collection always was remained dependent on a handful of elderly stationary balers with top-feed ram stroke and wire/plastic twine tie design, and straw was shipped in rectangular bales for instance $0.6 \times 0.5 \times 1.5 \mathrm{~m}$ (width, height and length). Bale length varied up to $1.9 \mathrm{~m}$. Mass was typically 100-120 $\mathrm{kg} / \mathrm{bale}$, but could be higher, which make this baling system classified as medium/large baling system. There is another smaller type of straw bale press is produced to fit the requirements of straw bale size of the client and it can be either used to press rice straw at its hay estate or in its chipped estate. Metal string or plastic ropes can be used to tie the straw bale, the baler move from place to place near the field to bale manually collected rice straw (Garas et al., 2009). More development done to improve the working efficiency with adequate safety in such balers e.g. El-Shal (2005) added a unit of straw pick up, packers, means of applying forces to resist the moving of material through the bale chamber, and means of separating consecutive bales. More straw baling machines came later and now are commonly used in some regions, and are ideally suited for harvesting straw from small fields, and the bale is convenient and easy-to-handle by small-scale producers. (Steele et al., 2009) 
In Pakistan, a mobile straw baler was designed and developed at the Agricultural Mechanization Research Institute (AMRI), Multan, Pakistan. The design parameters of this mobile straw baler were based on local farm size, crop wastes and field conditions. The baler made bales of size approximately $0.391 \times 0.457 \times 0.635 \mathrm{~m}$, handling of the bales was simple and easy. The loading and transportation of bales with a truck and trolley was easy and cheaper than that of the straw. The cost of manufacturing was $\$ 3800$ and the average weight of wheat straw bale was $34.6 \mathrm{~kg}$. However no data about the performance of this baler with rice straw (Yasin, 2012). In India and china, systems needed for the collection, processing, and transportation of rice straw have been developed recently. Many balers are available for collecting rice straw with bale size of $0.46 \mathrm{x}$ $0.36 \mathrm{~m}$ (height and width) with variable length from 0.4 to $1.1 \mathrm{~m}$ and bale weight is from 10 to $35 \mathrm{~kg}$ depending on bale length and crop condition (Mangaraj and Kulkarni, 2011; HSCUP, 2011). Some of straw bales get transferred by medium and big trucks to nearest power plants (Romana, 2013). In some African countries, e.g. in Ghana, the rectangular balers are used now in some places for baling rice straw mainly as cattle's feed (MOFA, 2013). But no local manufacturing or assembling operations running in the country, all available balers are imported.

However rice threshers have been used widely and farmers will continue to use them for more many years, even with increasing the number of combine harvesters and reapers, no better utilization of straw till now. Also, the power sources available in most of developing counties are normally in term of small engines and two wheel tractors (2WTs), beside small/medium four wheel tractors (4WT) in some places. So, manufacturing and testing stationery small mobile baler was the aim of this study, where farmers can bale and easily transfer the amount of straw left after threshing operation or manually collected after combine harvesting.

\section{MATERIALS AND METHODS}

Hydraulic based baler was manufactured in local workshop in Los Baños city, Philippines to be operated by small-size engines from 5-10 hp or to be driven by electrical motor 3-10 hp to operate a hydraulic cylinder producing linear force and motion for the piston rod in a certain stroke by 
employing the flow of pressurized fluid. Manufactured baler has been tested and evaluated in International Rice Research Institute, Los Baños, Philippines during year 2013-2014. Major component of the baler were; hydraulic system consisted of PVR-15 vane pump with 400-1500 psi and keyed shaft standard, top-ported pressure filter, pressure gauge, sight gauge, return filter and piston with $600 \mathrm{~mm}, 0.083 \mathrm{~m} \mathrm{~s}^{-1}$ and $0.069 \mathrm{~m} \mathrm{~s}^{-1}$ stroke length, forward speed and return speed respectively; baler body with compression chamber has dimension of $600 \times 350 \times 450 \mathrm{~mm}$ (height $\mathrm{x}$ width $\mathrm{x}$ length) from inside; attached engine and transmission systems. The baler has been tested three times after assembling followed by baling rice straw coming from different rice varieties and harvesting methods under constant motor speed (in case of using electric motor) of $1790 \mathrm{rpm}$, pump speed of $1128 \mathrm{rpm}$ and 400-600 psi pressure applied.

\section{Technical Consideration}

Main technical considerations to manufacture the stationery baler were listed as below:

1- The small size of holdings and high cost of imported baling machines are indicators to have small-size bales produced economically. And to be driven by small size engines or electrical motors.

2- Avoiding complicated parts in baler parts which cannot be achieved with limited available skill workers and materials.

3- Providing suitable bales' weight and dimensions to be easily handled by one person.

4- Obtaining well-formed high density bales with straw pressing mechanism

\section{Pre-design Assumptions}

As we target producing economical small-scale bales, from literature review the dimensions of small scale bales are being varied, where, the most common bales dimensions around $\pm 400 \times 500 \times 600 \mathrm{~mm}$ ' we assumed that we can get bales with $600 \times 350 \times 450$ (h x w x l) mm with an overall size of $0.0945 \mathrm{~m}^{3}$ which give us reasonable weight (Figure 1). Target baling density was from $140-180 \mathrm{~kg} \mathrm{~m}^{-3}$ as recommended due moister variation, expected weight should be from 13 to $25 \mathrm{~kg} /$ bale. 


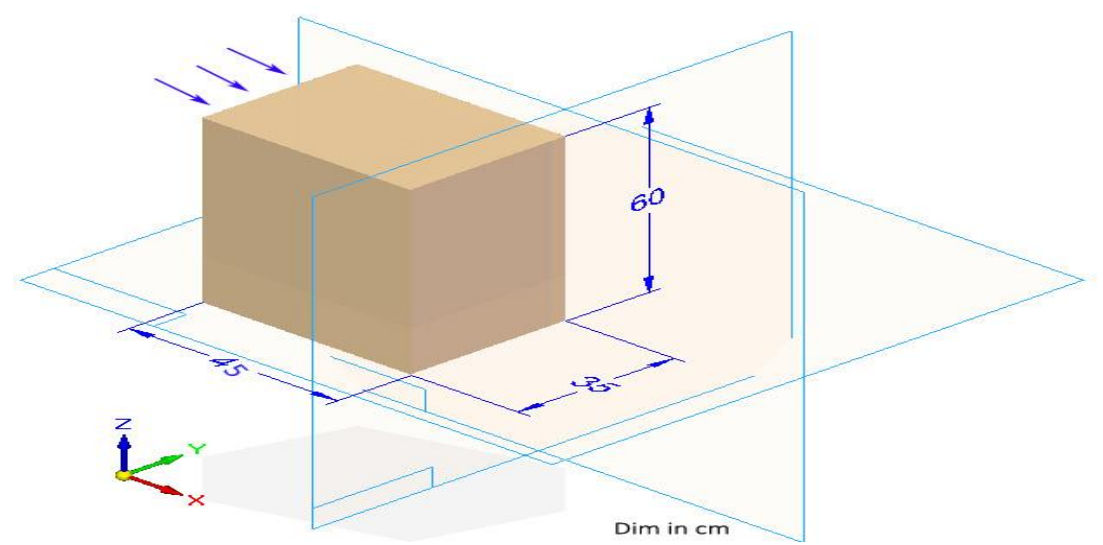

Figure 1: Assumed bale's dimensions

For the straw coming from threshers 'output, considering the two available options; 1) manual feeding by one person or, 2) $1000 \mathrm{~kg} \mathrm{~h}^{-1}$ as thresher feeding rate (average), straw coming to the baling chamber around $70 \%, 700 \mathrm{~kg}$ (after excluding the amount left on field and as of 1:1 straw ratio). In both cases we assumed that there is $700 \mathrm{~kg}$ of straw to be baled within one hour. $700 \mathrm{~kg}$ to be baled into certain number of bales with $18 \mathrm{~kg}$ average weight, then baling efficiency will be $38 \mathrm{bales} / \mathrm{h}$. That is happening only if the baling operation is continuous and every formed bale come out from baler without interface the next bale. That number of bales can be achieved only with a mechanical plunger compression system with a flywheel. But, the required parts and technical skills need to generate this design wasn't exist in local workshops. The alternative option was using a hydraulic system which was available instead of the using mechanical plunger; using hydraulic system is limiting the number of expected baled as hydraulic circuits provide slower motion to compression piston. As described earlier by Kepner et al (1987), from 150 to $180 \mathrm{~kg} \mathrm{~cm}^{-2}$ (which hydraulic system can easily provide) is enough force to generate bales with densities varied from 130 to $300 \mathrm{~kg} \mathrm{~m}^{-3}$ according to the moisture content of the straw. So, the hydraulic system was used to operate the compression piston.

\section{Hydraulic System}

Using 5 to $10 \mathrm{hp}$ engine [or electrical motor (3-10 hp)] is enough to operate a hydraulic cylinder to produce linear force and motion for the 
piston rod in certain stroke by employing the flow of pressurized fluid. The fluid is supplied by a mechanical pump. During compression, oil from the pump passes through a directional control valve, is split by the flow divider and fed to the full-bore side of the compression piston. Once it reaches the hydraulic cylinder, the pressurized oil exerts pressure upon the area of the piston inside the cylinder barrel. This pressure produces a large force that moves the piston. In order to prevent the hydraulic pressure from being lost by passing over the piston to the opposite side, hydraulic seals are installed in the piston, in our case; flow from pump is used to produce a piston velocity of approximately $0.14 \mathrm{~m} \mathrm{~s}^{-1}$. A compressor and gauge are used to regulate the pressure within the system. Typical hydraulic cylinders circuit and component used with baler as in Figure 2.

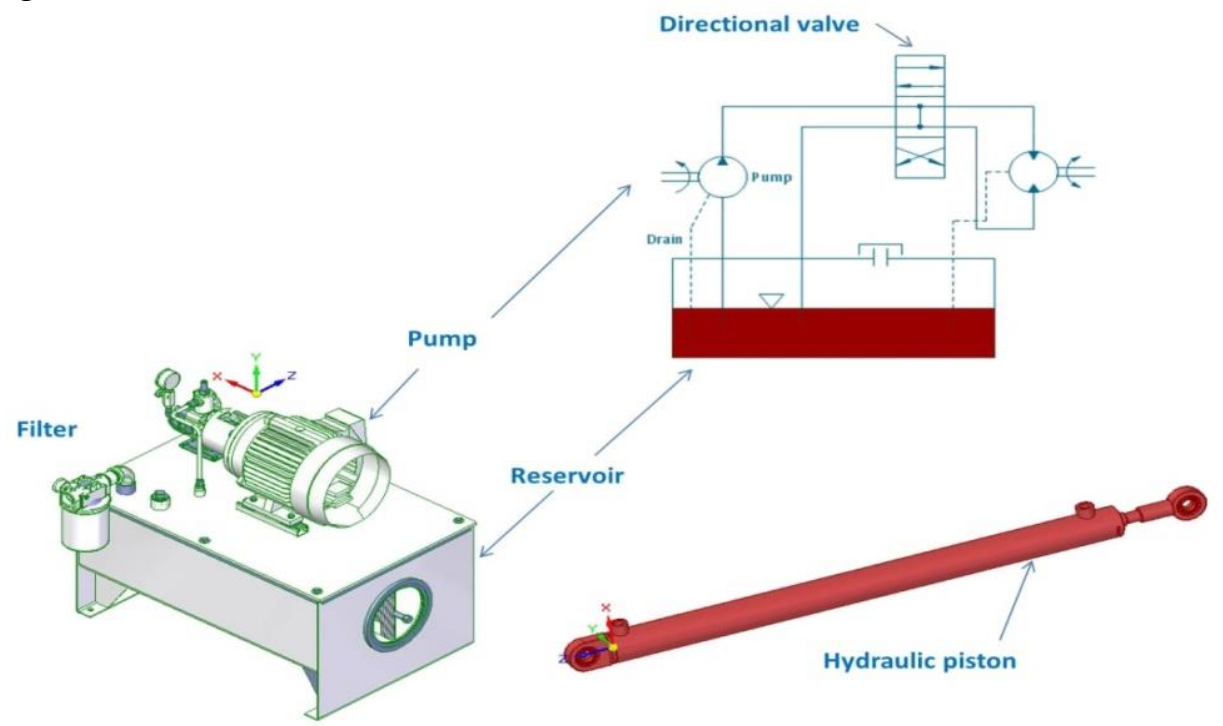

Figure 2: Simple acting cylinder circuit and components

Major components of the hydraulic system were: vane pump with specification listed in Table 1 and Figure 3, top-ported pressures filter (Table 2), pressure gauge up to $2000 \mathrm{psi}\left(0-140 \mathrm{~kg} \mathrm{~cm}^{-2}\right)$, sight gauge which gives an indication of current fluid level, and return filter. 

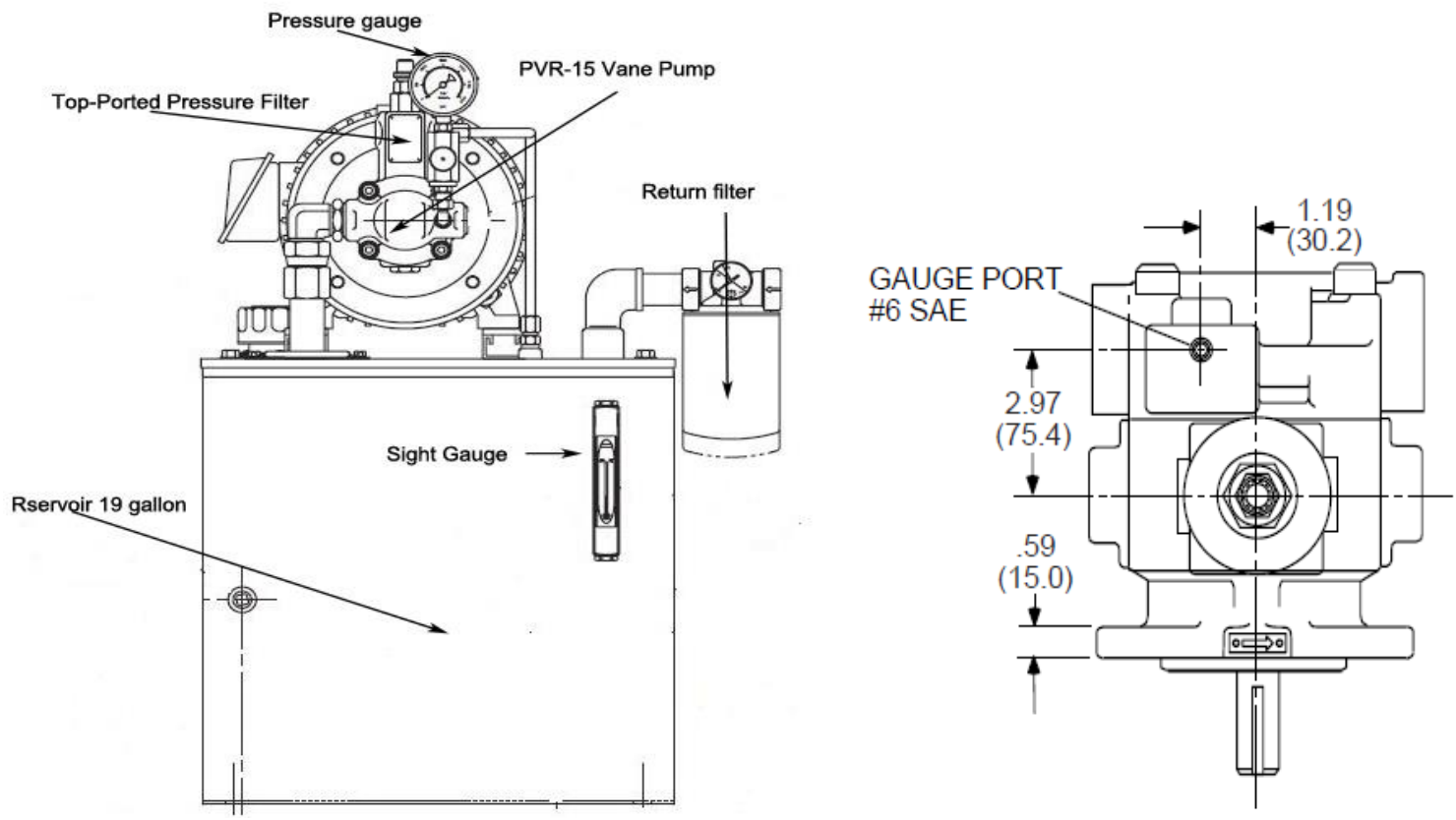

Figure 3: PVR-15 vane pump and its dimensions (15B 15-RF0-5-E, actual 400 -1500 Psi - keyed shaft standard) used in the hydraulic system

Table1: Typical performance specifications of PVR-15 vane pump used in the hydraulic system

\begin{tabular}{|c|c|c|c|}
\hline \multicolumn{4}{|c|}{ Pump Size 15b 15 - flanged mounted SAE "B" 2-Bolt } \\
\hline \multicolumn{2}{|c|}{ Volumetric displacement } & cu. in./rev. (ml/rev.) & $2.4(39.3)$ \\
\hline \multirow{2}{*}{\multicolumn{2}{|c|}{ Pump delivery at $1750 \mathrm{rpm}$}} & 91.5 psi (6.3 bar) & gpm 18.7 (lpm 70.8) \\
\hline & & Rated pressure & gpm 15 ( lpm 56.8) \\
\hline \multirow{3}{*}{\multicolumn{2}{|c|}{ Compensated pressure ranges }} & Max. & psi 2000 (bar 160) \\
\hline & & Rated & psi 2000 (bar 138) \\
\hline & & Min. & psi 400 (bar 28) \\
\hline \multirow{3}{*}{\multicolumn{2}{|c|}{ Operating speeds }} & Min. & rpm 1400 \\
\hline & & Rated, rpm & 1750 \\
\hline & & Max., rpm & 2400 \\
\hline \multirow{4}{*}{ Suction } & \multirow{3}{*}{ pressure } & Max. & psi 20 (bar 1.40) \\
\hline & & Min. & in./Hg 7 \\
\hline & & Specific gravity $<1$ & bar -0.25 \\
\hline & Fluid velocity & Max. & ft./sec. $5(\mathrm{~m} / \mathrm{sec} .1 .5)$ \\
\hline \multirow{4}{*}{$\begin{array}{l}\text { Case } \\
\text { Crain }\end{array}$} & \multirow{3}{*}{$\begin{array}{l}\text { Nominal flow at deadhead } \\
\text { pressure }\end{array}$} & 1000 psi (69 bar) & gpm $0.5(1 \mathrm{pm} \mathrm{1.9)}$ \\
\hline & & 1500 psi (103 bar) & gpm $0.8(1 \mathrm{pm} 3.0)$ \\
\hline & & 2000 psi (138 bar0 & gpm 1.2 (lpm 4.5) \\
\hline & Maximum case pressure & \multicolumn{2}{|c|}{ psi $10($ bar 0.7) } \\
\hline
\end{tabular}


Table 2: Top-Ported Pressure Filter

\begin{tabular}{|l|l|}
\hline \multicolumn{2}{|l|}{ Top-Ported Pressure Filter } \\
\hline Rating: & Up to $20 \mathrm{gpm}(75 \mathrm{~L} / \mathrm{min})$ for $150 \mathrm{SUS}(32 \mathrm{cSt})$ fluids \\
\hline Max. operating pressure: & $3000 \mathrm{psi}(210 \mathrm{bar})$ \\
\hline Rated fatigue pressure: & $2400 \mathrm{psi}(165 \mathrm{bar})$ \\
\hline Temp. range: & $-20^{\circ} \mathrm{F}$ to $225^{\circ} \mathrm{F}\left(-29^{\circ} \mathrm{C}\right.$ to $\left.107^{\circ} \mathrm{C}\right)$ \\
\hline Porting Head: Element Case: & Aluminum \\
\hline Weight of NF30-1N: weight of NF30-1NN: & $3.4 \mathrm{lbs} .(1.5 \mathrm{~kg}) 4.4 \mathrm{lbs} .(2.0 \mathrm{~kg})$ \\
\hline Element change clearance: & $4.50^{\prime \prime}(115 \mathrm{~mm})$ \\
\hline
\end{tabular}

\section{Evaluation, Study Variables and Parameters}

To define the relationship between bales density and rice straw condition at constant applied pressure, piston speed, bale chamber size, cycle of loading and feed rate, the variables (factors having an influence on bales density) were; different moisture contents; length of straw (harvesting methods); and varieties. Different levels have been tested to represent different moisture may exist after harvesting and according to the number of days after harvest or weather condition. Harvesting methods included combine harvesting and manual harvesting which either followed by manual or axial flow threshing, which is affecting straw length. the evaluation experiments done under constant stroke length of $600 \mathrm{~mm}$, piston forward speed of $0.083 \mathrm{~m} \mathrm{~s}^{-1}$ piston return speed of $0.069 \mathrm{~m} \mathrm{~s}^{-1}$, compression chamber with dimension of $600 \times 350 \times 450$ (h x w x l) mm.

\section{Manufacturing and Pre-testing of The Hydraulic Baler}

After assembling different baler parts and components including the hydraulic system, three consecutive tests were done to enhance the baling mechanism, bale delivering system, and straw feeding.

\subsection{First Test}

No issues or problems found regarding the use of hydraulic system or the attached engine, major problems found were related to; 1) feeding straw with required compression force in front of the compression rod sheet (Figure $4 \mathrm{c}$ ); 2) difficulties to get formed bales out of the compression chamber (Figure $4 \mathrm{~b}$ ), it is supposed to be manually pulled away for tying. There was no easy solution to overcome the problem of getting the bales out of the baler except changing the way of getting bales out from side way to the back end of the baler. Then, the baler outlet opening has been 
changed to be at the end using the compression piston to push the bales out of the baler to be tied. The problem of compression force required in front of the compression piston sheet solved by adjusting the hopper to make a smooth flow of the straw and to be an option to attach it or not according to the straw situation and the speed of straw feeding.

\subsection{Second Test}

Second test came with better results, and the observations were related to the tying mechanism which normally being done manually. One observation was to add two more tying strings perpendicularly to the other three main strings (Figure $4 \mathrm{e}$ and $\mathrm{f}$ ). Other modifications followed second test which included but not limited to; better screw bolt stand, more tying string houses, changing the hydraulic system control arm to work up and down instead of right and left with adding lock to provide continues movement of the compression piston without fully human control.
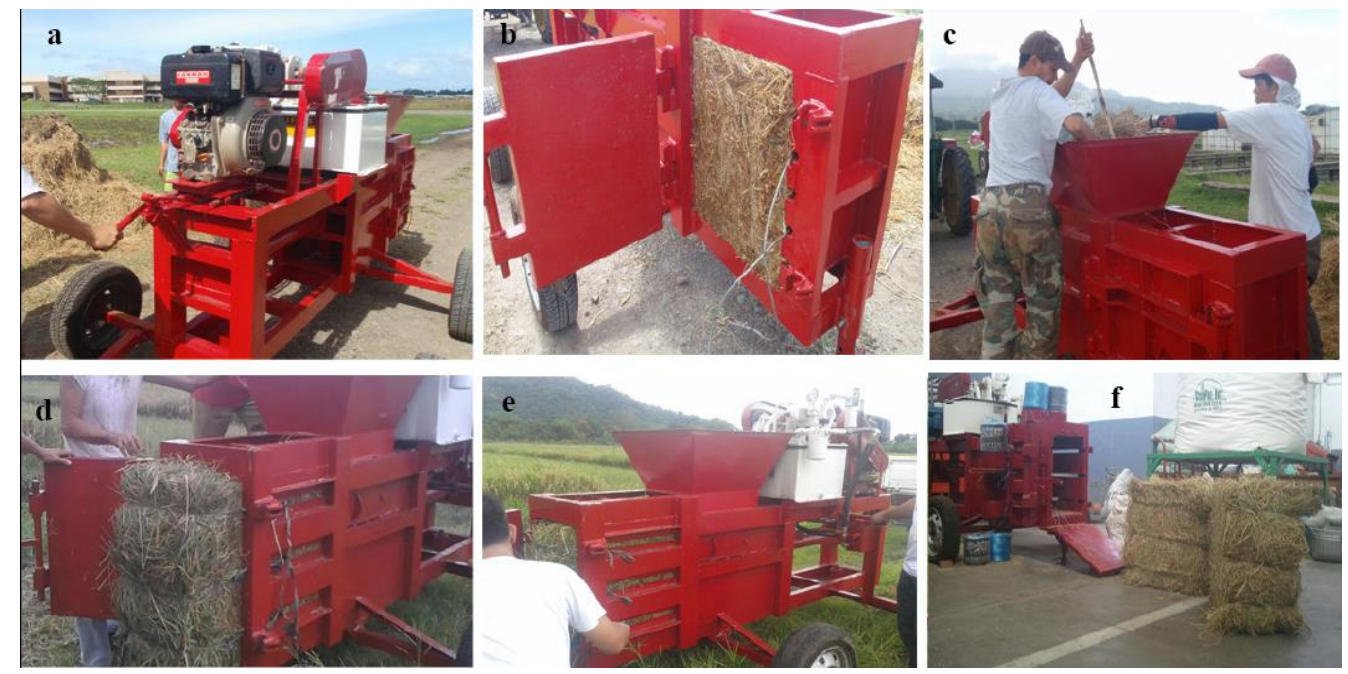

Figure 4: Consecutive testing to enhance the baling mechanism and tying system

\subsection{Third Test}

Mainly was to test the reliability of the system for long time operation, and the system worked well without any observation of low pressure, leakage or overheating. Successfully, the baler delivered 40 bales continuously. Robin model EY23 air-cooled $10 \mathrm{hp}$ gasoline engine or electrical motor have been used in testing (Figure 5). The final geometric and technical drawings of baler are shown in Figure 6. 


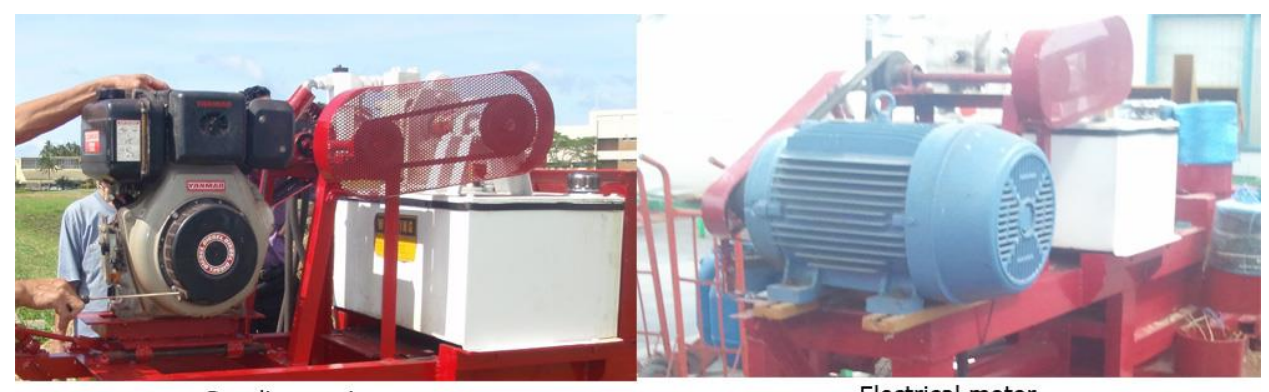

Gasoline engine

Electrical motor

Figure 5: Two options to operate the manufactured baler

Scale: 1:16
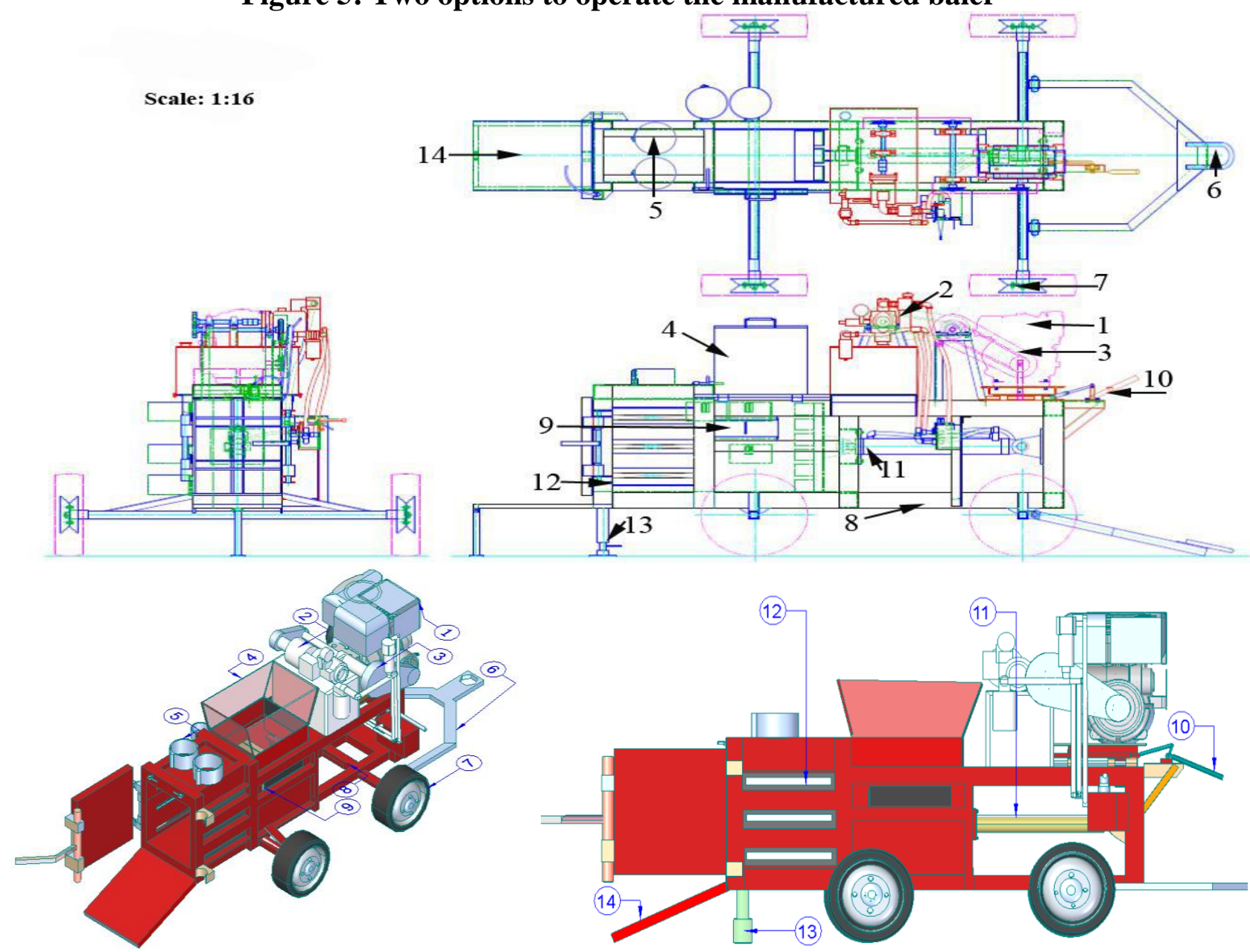

1) Engine, 2) hydraulic system, 3) transmission system, 4) hopper, 5) twine holder, 6) one-point hitch, 7) wheel, 8) frame, 9) sliding window, 10) placement arm, 11) piston,

12) tying opening, 13) screw stand bolt, 14) straw skating sheet

Figure 6: Geometric and technical drawing of manufactured baler 


\section{RESULTS AND DISCUSSION}

Densification experiments have been done to evaluate the baler output under different rice straw condition.

With mix varieties harvested by combine and have stem length of 448 $\mathrm{mm}$, average density was about $176.63 \mathrm{~kg} \mathrm{~m}^{-3}$ when straw got baled in same harvesting day under high moisture content of $25.23 \%$. same straw has been densified to $145.63 \mathrm{~kg} \mathrm{~m}^{-3}$ when baled after 13 days at lower moisture content $(7.77 \%)$. percentage decrease in density was $17.6 \%$ when moisture content in straw decreased by $69.2 \%$ (Figure 7). With two mix varieties (NSIC RC222 and NSIC RC238) which manually harvested and panicle threshed with short stem length of $276.67 \mathrm{~mm}$, average density was about $293.22 \mathrm{~kg} \mathrm{~m}^{-3}$ when straw got baled after 6 days from harvesting at high moisture content of $27 \%$. Same straw has been densified to $203.24 \mathrm{~kg} \mathrm{~m}^{-3}$ when baled after 22 days at lower moisture content $(9.26 \%)$. percentage decrease in density was $30.7 \%$. The high density obtained under high and low moisture content may be achieved because of the more densification applicable to short rice straw stem compared to the normal stem lengths (Figure 8).

Mix varieties, average stem length of $448 \mathrm{~mm}$, distributed equally in $25.23 \% \mathrm{MC}$

field

$7.77 \% \mathrm{MC}$

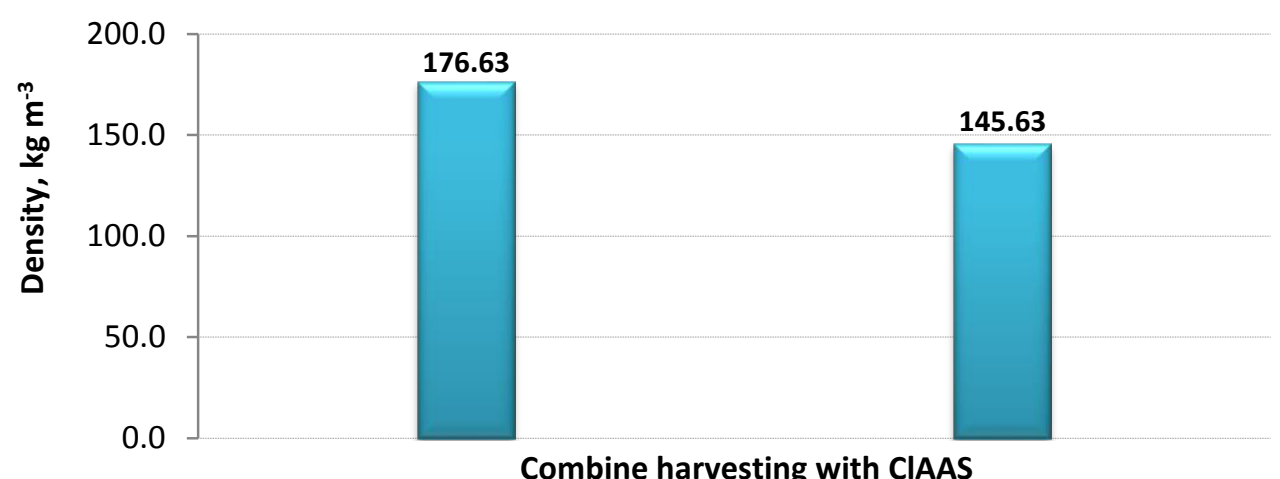

Figure 7: Densification of mix varieties harvested by combine and have stem length of $448 \mathrm{~mm}$. 
Mix varieties (NSIC RC222+NSIC RC238), average stem length of 276.67 $\mathrm{mm}$, kept in sacks indoors

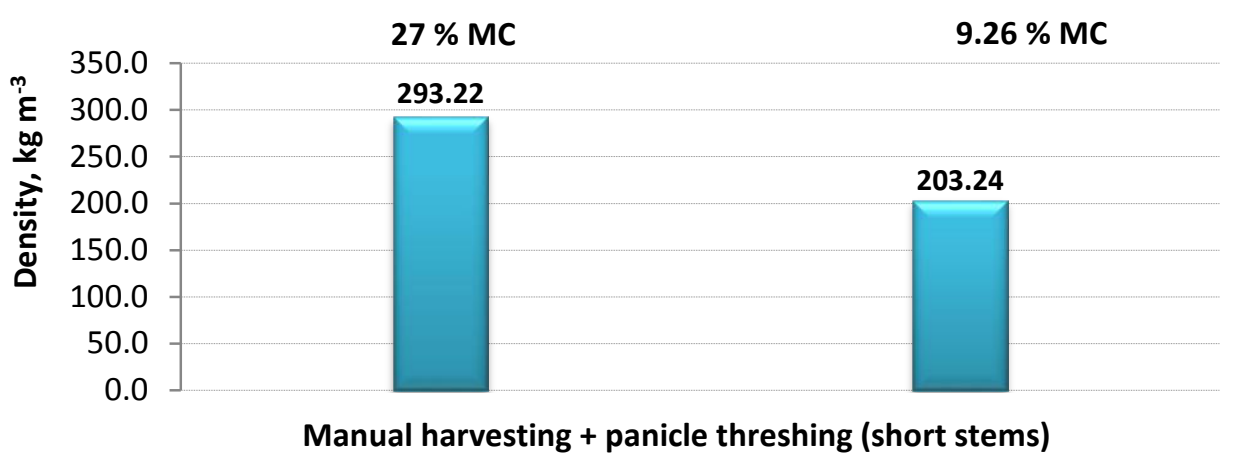

\section{Figure 8: Densification of manually harvested and panicle threshed with short stem length of $276.67 \mathrm{~mm}$.}

Manually harvested rice variety NSIC RC222 followed by axial flow threshing which has stems with average lengths of $640 \mathrm{~mm}$ gave density of $148.24 \mathrm{~kg} \mathrm{~m}^{-3}$ when baled with $8.65 \%$ moisture content after 22 days of harvesting. Same straw has been densified to $137.53 \mathrm{~kg} \mathrm{~m}^{-3}$ when baled 2 days after harvesting at $8.21 \%$ moisture content (Figure 9). Percentage increase in density was $7 \%$ and the straw absorbed more moisture from surrounding air within 22 days of storage inside door.

Rice straw baled under low moisture content when gets stored indoors long time, always had an increase in its moisture content, e.g. NSIC RC238 variety which harvested manually and threshed by axial flow threshed with $444 \mathrm{~mm}$ stem length, when stored for 62 days, its moisture content increased from 6.31 to $8.78 \%$. And, the density in this case increased by $3.4 \%$ with the increase of the moisture content. For the two varieties NSIC RC222 and NSIC RC238 which have been manually harvested and manually threshed with 626 and $598 \mathrm{~mm}$ stem length, the percentage increase of moisture content was $29 \%$ and $31.6 \%$ respectively when stored for 62 days prior to baling. In both verities NSIC RC222 and NSIC RC238, the density of straw has been increased by 4.1 and $2.7 \%$ respectively (Table 4 and Figure 10). Type II sum of squares analysis showed the high significance of the moisture content in baling densities with developed baler as known fact and expected results with standard division of 48.713 . 
NSIC RC222, average stem length of $640 \mathrm{~mm}$, kept in sacks indoors

$8.21 \% \mathrm{MC}$

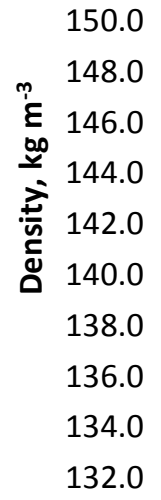

137.53

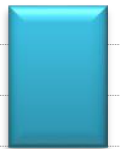

$8.65 \% \mathrm{MC}$

148.24

Manual harvesting + axial flow threshing

Figure 9: Densification of Manually harvested rice followed by axial flow threshing.

Table 4: Characteristics of different baled rice straw after 62 days of inside door storage.

\begin{tabular}{|c|c|c|c|c|c|c|c|}
\hline Variety & $\begin{array}{c}\text { Date of } \\
\text { baling in } \\
2014 \\
\end{array}$ & Harvesting method & $\begin{array}{c}\text { Stem } \\
\text { length, } \\
\text { mm }\end{array}$ & $\begin{array}{c}\text { Stem } \\
\text { thickness, } \\
\text { mm } \\
\end{array}$ & $\begin{array}{l}\text { Days after } \\
\text { harvesting }\end{array}$ & $\begin{array}{c}\text { Moisture } \\
\text { content, } \\
\% \\
\end{array}$ & $\begin{array}{l}\text { Density, } \\
\mathrm{kg} / \mathrm{m}^{3}\end{array}$ \\
\hline $\begin{array}{c}\text { NSIC RC } \\
238\end{array}$ & 04, April & $\begin{array}{l}\text { Manual harvesting } \\
\text { +axial flow threshing }\end{array}$ & 444 & 3.03 & 2 & 6.31 & 130.37 \\
\hline $\begin{array}{c}\text { NSIC RC } \\
238\end{array}$ & 29, May & $\begin{array}{l}\text { Manual harvesting + } \\
\text { axial flow threshing }\end{array}$ & 444 & 3.03 & 62 & 8.78 & 134.74 \\
\hline NSIC RC222 & 10, April & $\begin{array}{c}\text { Manual harvesting + } \\
\text { Manual threshed }\end{array}$ & 626 & 3.20 & 10 & 6.45 & 149.07 \\
\hline NSIC RC222 & 29, May & $\begin{array}{c}\text { Manual harvesting + } \\
\text { Manual threshed }\end{array}$ & 626 & 3.20 & 62 & 9.12 & 155.25 \\
\hline $\begin{array}{c}\text { NSIC RC } \\
238\end{array}$ & 10, April & $\begin{array}{c}\text { Manual harvesting + } \\
\text { Manual threshed }\end{array}$ & 598 & 2.90 & 10 & 6.02 & 134.4 \\
\hline $\begin{array}{c}\text { NSIC RC } \\
238\end{array}$ & 29, May & $\begin{array}{c}\text { Manual harvesting + } \\
\text { Manual threshed }\end{array}$ & 598 & 2.90 & 62 & 8.8 & 138.09 \\
\hline
\end{tabular}




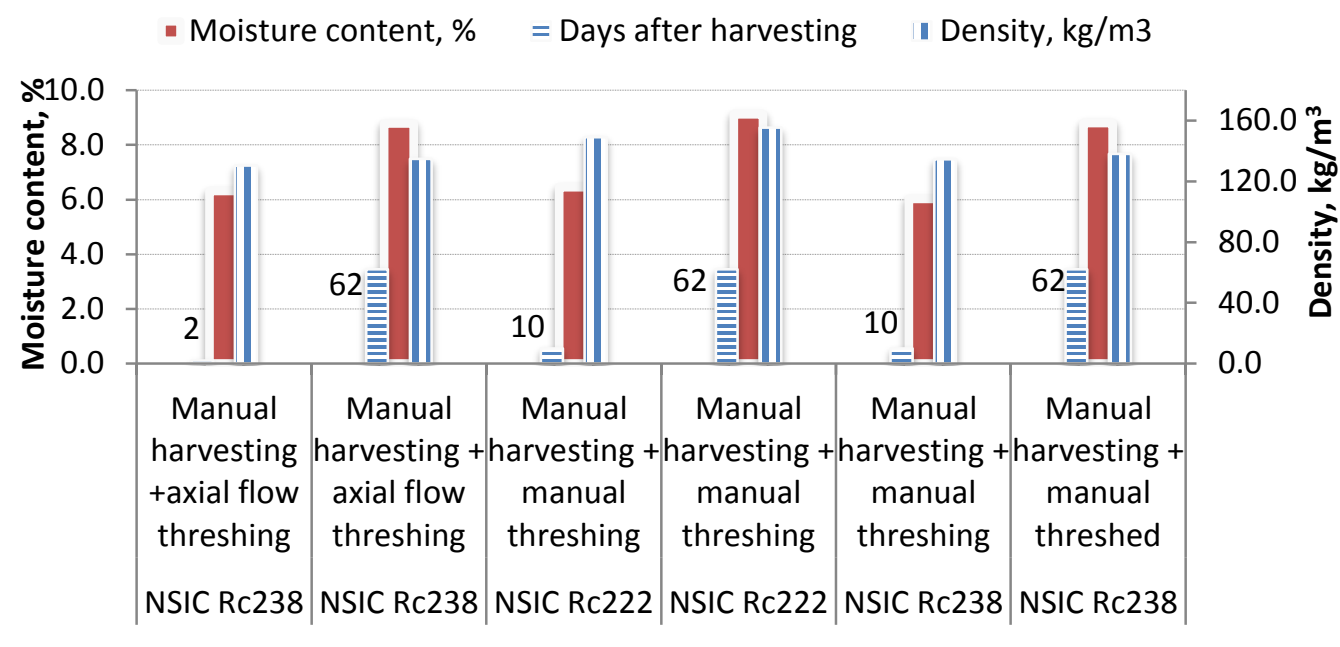

Variety, harvesting and threshing method

Figure 10: Densities of different rice straw bales after 62 days indoor storage.

Along with the effect of moisture content of rice straw baling, both rice straw length and stem thickness have been measured before baling. Results showed the significance of straw length on density, where short straw with average $276.67 \mathrm{~mm}$ which came due to manual harvesting followed by panicle threshing gave highest densities with averages of 293.22 and $203.24 \mathrm{~kg} / \mathrm{m}^{3}$ at moisture content of 27 and $9.26 \%$ respectively. While longer stems which have 448 to $626 \mathrm{~mm}$ length gave densities from 130.37 to $176.63 \mathrm{~kg} / \mathrm{m}^{3}$ at different moisture contents as shown in Figure 11. All rice straw thicknesses were in range from 2.63 to $3.30 \mathrm{~mm}$ in average and have no significant effect on bales' densities.

\section{CONCLUSIONS}

The developed baler has ability to produce bales with recommended and designed dimensions with bales weight ranged from 11.13 to $28.33 \mathrm{~kg}$ and $600 \times 350 \times 450 \mathrm{~mm}$ as bales dimensions. For mix varieties which harvested by combine and have average stem length of $448 \mathrm{~mm}$, density decreased by $17.6 \%$ when moisture content in straw decreased by $69.2 \%$. Baling manually harvested mix varieties with average stem length of $276.67 \mathrm{~mm}$ gave highest bales' densities of $293.22 \mathrm{~kg} \mathrm{~m}^{-3}$ at high moisture content of $27 \%$ and $203.24 \mathrm{~kg} \mathrm{~m}^{-3}$ at lower moisture content $(9.26 \%)$. 


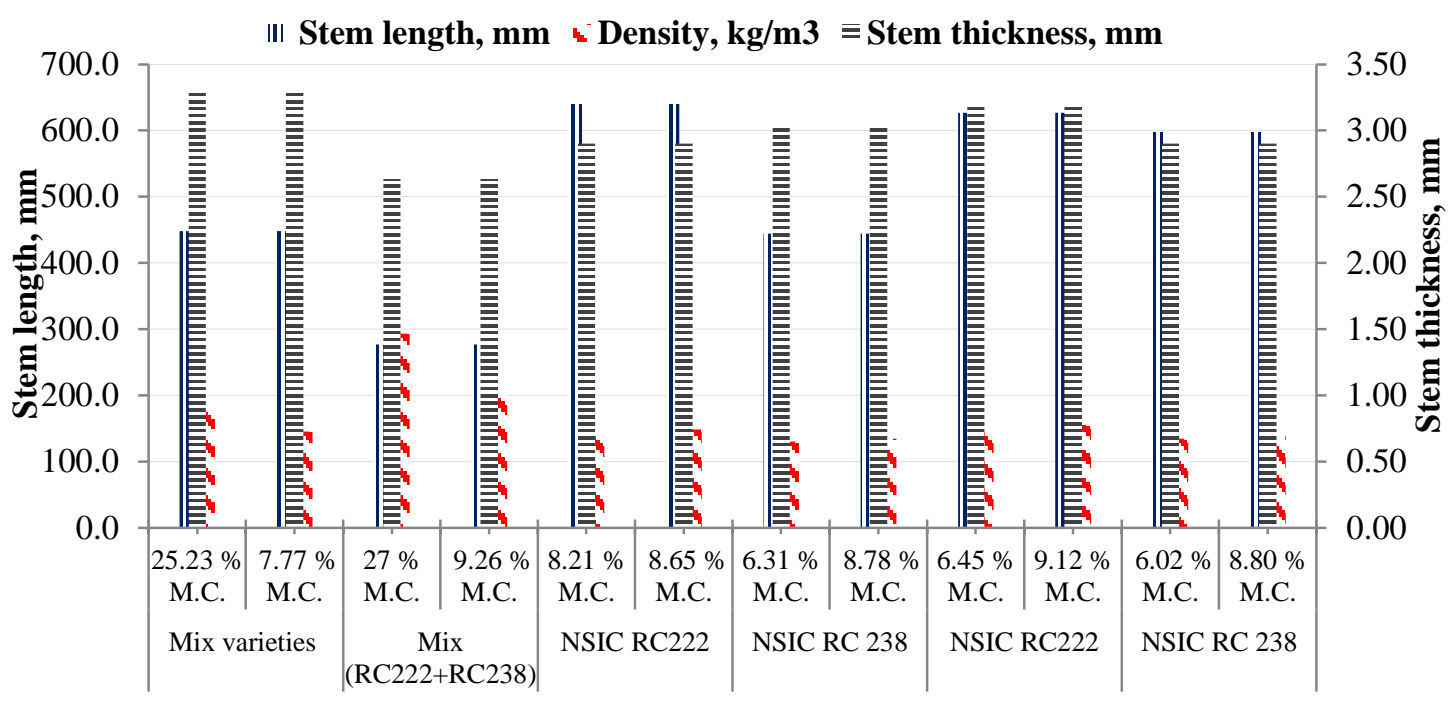

Harvesting method /baling moisture content \%

Figure 11: Effect of rice straw length and thickness on bales' densities.

Storing straw indoors with lower moisture slightly led up to increase in straw moisture content e.g. in case of manually harvested rice variety NSIC RC222, moisture content increased from $8.21 \%$ to $8.65 \%$ when straw stored for 22 days indoor, which gave increasing in density by $7 \%$ in average. Other rice straw stored indoors under low moisture content for long time had same trend of increasing their moisture content with increase bales densities.

Distribution such simple small/medium scale balers within farmers will assist in baling straw left after threshing or manually collected after combine harvesters in small or large farms. Results are suitable to guide different stakeholders to bale rice straw under different conditions. And that will enhance straw handling, transportation and storage which are important to start any rice straw based conversion technology and utilization. However, further studies need to address the economic use of such machines compared to big/medium size balers with force analysis and energy requirements for operating the baler.

\section{ACKNOWLEDGMENTS}

The author would like to thank Postharvest Unit technicians and all IRRI Experiment Station staff for their invaluable support during his working time as post-doctoral research fellow. 


\section{REFERENCES}

El-Shal, A.M. (2005). Development of stationary baler to improve its performance for baling residues of some field crops. Unpublished Ph.D. thesis, Zagazig University, Egypt, P: 53-70.

Garas, G.L., M. E., Allam, H. M. El Kady, and A. H. El Alfy (2009). Compressibility of Single Un-Rendered Rice Straw Bales: Characteristics of Bales Used For Building. ARPN Journal of Engineering and Applied Sciences, Vol. 4, No. 5, P: 64-90.

Gummert, M. (2013). Rice straw and husks. Our Science, IRRI, Accessed on October 2013. Available at: http://irri.org/index.php?option=com_k2\&view=item\&id=9967:stra w-and-hull\&lang=en

Hanafi, E. M., H. H. El Khadrawy, W. M. Ahmed, and M. M.Zaaba (2012). Some Observations on Rice Straw with Emphasis on Updates of Its Management. World Applied Sciences Journal 16 (3), P: 354-36.

HSCUP (2011). Hunan Straw Comprehensive Utilization Planning, Hunan Economic and Information Technology Commission 2010. Changsha, China.

Kepner, R.A., R. Bainer, and E.L. Barger (1978). Principles of farm machinery. 3rd. ed. the AVI Pub. Co., Inc. USA: 341-357.

Mangaraj, S. and S.D. Kulkarni (2011). Field Straw Management - A Techno Economic Perspectives. Journal of the Institute of Engineering, Vol. 8 (1), P: 153-159

MOFA (2013). The Ministry of Food and Agriculture, GHANA, accessed on April, 2013. Available at: http://mofa.gov.gh/site/?page_id=4145.

Romana, M. (2013). India Increases Effort to Harness Biomass Energy. Energy and Environment. The New York Times. Available at: http://www.nytimes.com/2013/10/09/business/energyenvironment/india-increases-effort-to-harness-biomassenergy.html? $\mathrm{r}=0$ 
Sarkar, N. and K. Aikat (2013). Kinetic Study of Acid Hydrolysis of Rice Straw. Hindawi Publishing Corporation, ISRN Biotechnology Volume 2013, Article ID 170615, P: 1-5.

Steele, P., A. El-Hissewy, and A. Badawi (2009). Technical Manual: Agro-Industrial Use of Rice Straw Project TCP/EGY/3102. Rural Infrastructure and Agro-industries Division, Food and Agriculture Organization of the United Nations, Regional Office for the Near East, Cairo, Egypt. ISBN: 978-977-302-258-2.

Yasin, M. (2012). Performance Evaluation of Mobile Straw Baler. J. Agric. Res., 2012, 50 (2), P: 261-270.

\section{الملخص العربى \\ تطوير وتقييم آله هيدروليكيه متنقله لتبيل قش الارز \\ د. دـاد عزيز حجازي}

الهدف الرئيسي من البحث هو تصنيع آله تبيل لقش الأرز مُشغله بنظام هيدروليكي ومُتنقله

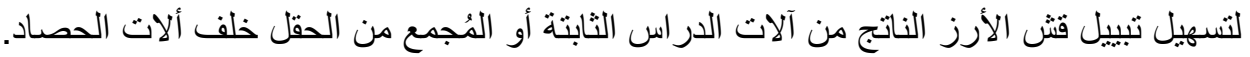

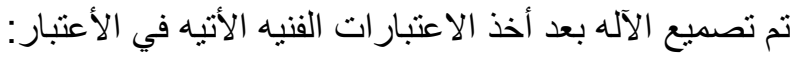

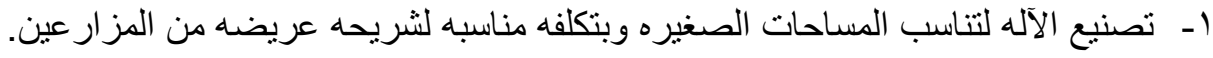
r- انتاج بالات من قش الأرز باحجام وأوزان سهله النقل و التخزين ويمكن تذاولها وحملها

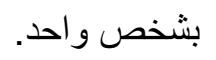

r- التغلب علي مشكله تر اكم قش الأرز علي جو انب الأراضي الزراعية والممارسات الغير

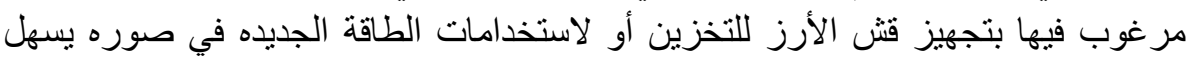

$$
\text { ادارته. }
$$

ع- تصميم سهل ويمكن تصنيعه في الورش المحليه وبخامات متاحه وبامكانيات فنيه بسيطه.

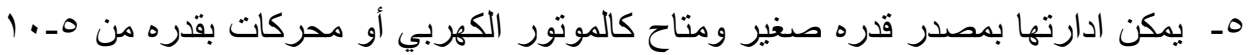
حصان.

تم تصنيع آله التبيل في احدي الورش المحلية في مدينه لوس بانوس اقليم لاجونا في الفلبين

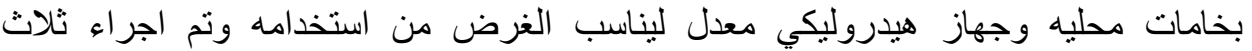
اختبارات لضبط وتعديل الآله اثناء التصنيع وتلافي بعض مشكلات التاتلات التشغيل اثثاء الاختبارات.

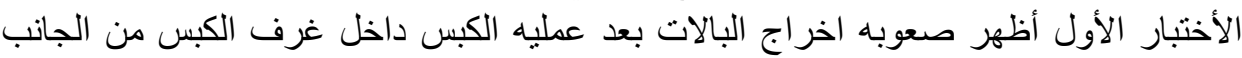

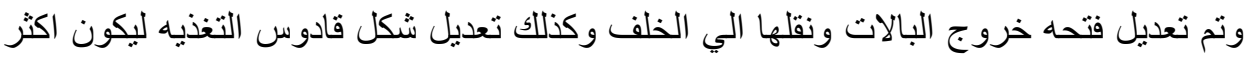

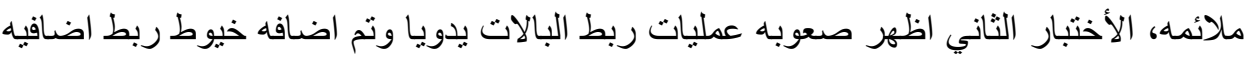

* مدرس الهندسة الزراعية ـ كلية الزراعة - جامعة كفر الثيخ. 
لاحكام وسرعه ربط البالات، الاختبار الثالث تم لقياس الأداء لفتره تشغيل طويله لكبس عدد أربعين باله دون وجود مشاكل فنيه في الآله. بعد التاكد من عدم وجود مشكلات فنيه اثناء

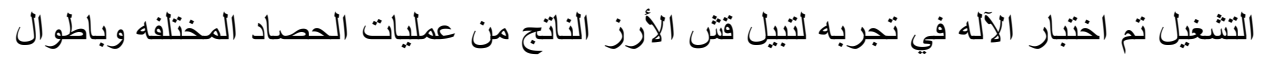

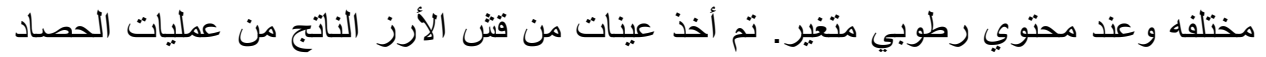

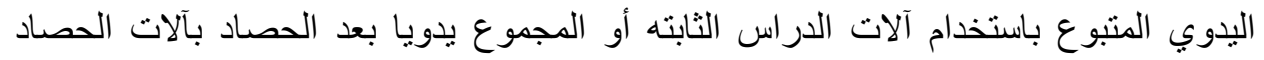

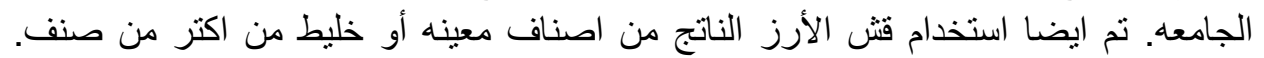

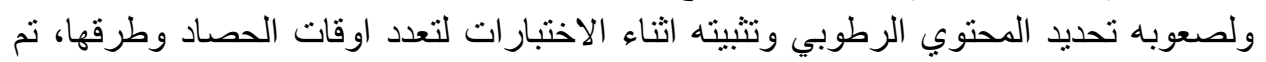
قياسه قبل وبعد عمليات التبيل وربطه بكثافه البالات مع الاشاره لأطو ال سيقان فش الأرز

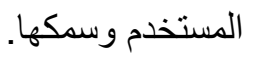

وقد أوضحث النتائج أن:

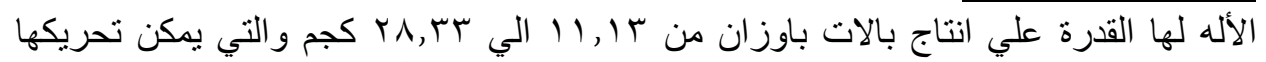

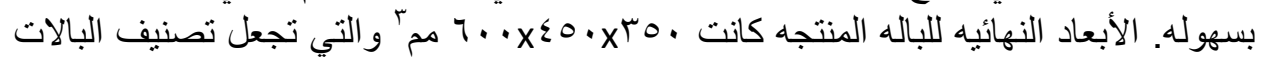
ضمن الأحجام الصغيره . قش الأرز بمتوسط طول ^^乞 مح والناتج من حصاد أكثر من صنفيين من محصول الأرز بآله

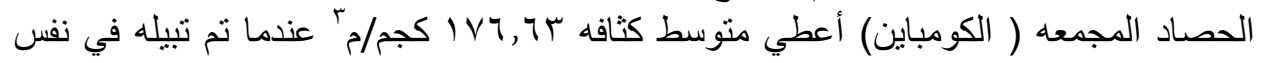

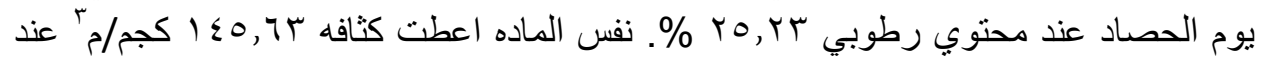

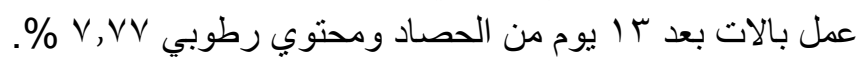
قش الأرز الناتج من صنفي الأرز NSIC RC222 و NSIC RC238 و المخلوطين معا

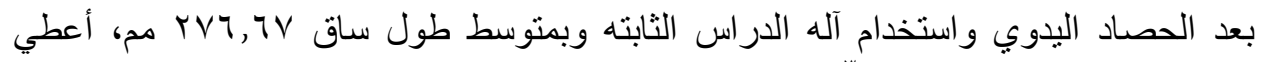

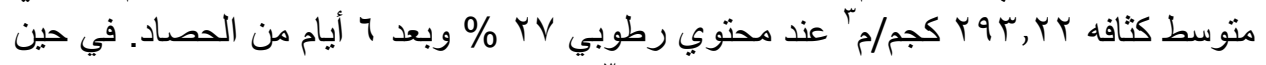

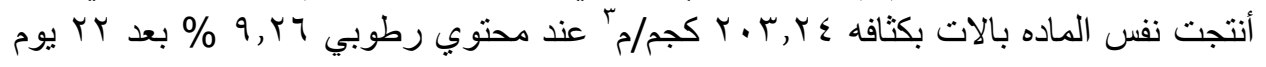

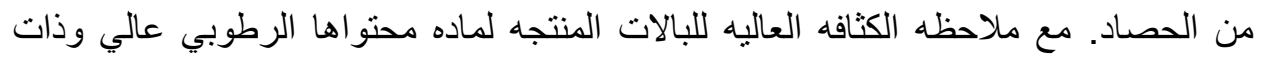
سيقان قصيره وهو ما يتفق مع معظد الدر اسات السابقه.

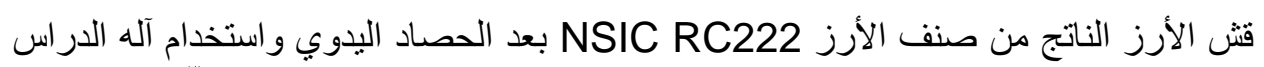

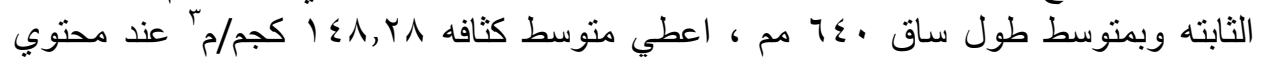

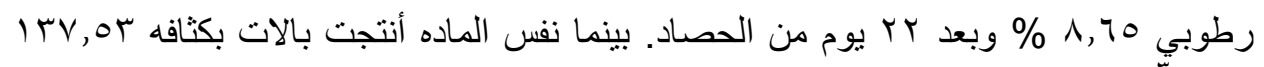

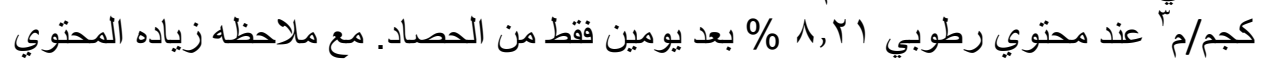

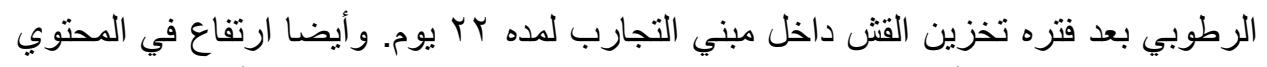

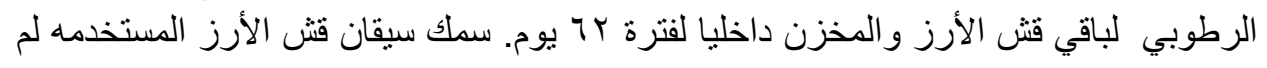
يكن له تاثثير ولكن السيقان القصيره اظهرت تاثير معنوي علي زياده الكثافه مع زياده المحتوي الرطوبي عند استخدام آله التبيل المصنيف ونسان. 